УДК 37.015.3:811.11(045)(477.82)

DOI: https://doi.org/10.35619/iiu.v0i9.3

\author{
Скробака Юлія \\ кандидат педагогічних наук, \\ викладач англійської мови \\ Луцького педагогічного коледжу, \\ м. Луцьк, Україна \\ ORCID: 0000-0001-5942-2783 \\ e-mail: chapiuk@ukr.net
}

\title{
РЕАЛЬНИЙ СТАН СФОРМОВАНОСТІ КРЕАТИВНОГО МИСЛЕННЯ МОЛОДШИХ ШКОЛЯРІВ У ПРОЦЕСІ НАВЧАННЯ ІНОЗЕМНИХ МОВ: ЦІЛЕ-МОТИВАЦІЙНИЙ КОМПОНЕНТ
}

\begin{abstract}
Анотація. У статті висвітлюються реальний стан сформованості креативного мислення молодших школярів у процесі навчання іноземних мов за цілемотиваційним компонентом як ключового щодо розвитку означеного феномена. Внесено уточнення щодо трактування понять «діагностування» та «діагностика». У логічній послідовності розкриваються методики, спрямовані на виявлення сформованості креативного мислення молодших школярів за ціле-мотиваційним компонентом. Виокремлено тести, спрямовані на виявлення сформованості креативного мислення молодших школярів за ціле-мотиваційним компонентом, зокрема, тест мотивації школяра до навчання у школі О. Ануфрієва та С. Костроміної та тест-питальник мотивації досягнення А. Мехрабіяна, створений для виміру мотиву прагнення до успіху і мотиву уникнення невдачі. У статті подається розроблений автором тест «Креативне мислення», який дає можливість визначити рівень сформованості креативного мислення молодших школярів у процесі вивчення іноземних мов за досліджуваним компонентом. Автором акцентується увага на недостатньому рівні сформованості мотиваційної складової щодо розвитку креативного мислення на уроках іноземної мови.
\end{abstract}

Ключові слова: креативне мислення, розвиток, ціле-мотиваційний компонент, методика.

Постановка проблеми. Необхідність розвитку креативного мислення окреслена в Державному стандарті початкової освіти, метою якого $\epsilon$ формування іншомовної комунікативної компетентності для безпосереднього та опосередкованого міжкультурного спілкування, а, отже, характеризується спрямованістю на особистісний результат кожного учня. У навчальному стандарті прописані усі види діяльності, якими повинен володіти молодший школяр. Головною цінністю навчання є саме діяльність, а не сукупність знань. Сума знань, здобутих у школі, відходить на другий план. Кожен учень повинен вміти висловлювати думки, почуття та ставлення, взаємодіяти з іншими усно, письмово та у режимі онлайн, використовуючи іноземну мову; використовувати прочитану інформацію та критично оцінювати іiі. Дитина повинна навчитися опановувати нові знання і види діяльності. Розвиток творчого мислення допомагає досягти поставлених завдань (Міністерство науки і освіти України, 2017). Тому перед практичною освітою постає завдання виховання творчої особистості, здатної креативно мислити і діяти в різних сферах життя і сформувати мотивацію до навчання. 
Аналіз останніх досліджень 3 проблеми. Зауважимо, значний внесок у розробку проблеми діагностування мислення загалом, і творчого мислення зокрема, внесли I. Аверіна, Г. Альтшуллер, Р. Амтхауер, Д. Богоявленська, Д. Векслер, Дж. Гілфорд, Х. Зіверт, Р. Кеттелл, Дж. Равен, М. Саллівен, П. Торренс, О. Тунік, О. Щебланова та ін.

Мета статті полягає у виявленні реального стану сформованості креативного мислення молодших школярів у процесі навчання іноземних мов за ціле-мотиваційним компонент.

Виклад основного матеріалу дослідження. Відтак, вважаємо за необхідне внести уточнення щодо трактування понять «діагностування», «діагностика». Ми солідарні 3 думкою С. Мартиненко (2010, с. 11), що «діагностування (від гр. «dia» - «прозорий » та «gnosis» - «знання») означає пояснення, розпізнавання. Його можна тлумачити і як отримання інформації про стан, і розвиток контрольованого об'єкта, його відхилення від норми. Діагностування перебуває у нерозривному зв'язку 3 прогнозуванням та проектуванням, які логічно завершують ланцюжок дослідницької процедури. Діагностика, наголошує науковець, - це система технологій, засобів, процедур, методик і методів висвітлення обставин, умов і факторів функціонування педагогічних об'єктів, перебігу педагогічних процесів, встановлення їх ефективності та наслідків у зв'язку із заходами, що передбачаються або здійснюються».

Ми погоджуємося 3 думкою науковців В. Беспалько (1989), А. Зотов (1973), що особливу важливість має констатувальний етап експерименту, оскільки результати формувального етапу значною мірою пов'язані 3 початковим (вихідним) станом явища, що вивчається і саме він дає можливість визначення реального стану, зокрема сформованості креативного мислення учнів початкових класів на уроках іноземних мов. Відтак, нами було розроблено програму дослідницько-експериментальної роботи, до якої включено такі елементи:

- виявлення реального стану та вихідних рівнів сформованості креативного мислення учнів молодших школярів при вивченні іноземних мов;

- аналіз даних, отриманих у результаті проведеної експериментальної роботи.

В умовах «тестового буму» в 20 -х роках XX ст. у США таке розуміння творчої обдарованості a, отже, такий підхід до іiі діагностики, став визначальним на кілька десятиліть уперед (Гуревич и Борисова, 1995). Класичні дослідження творчого мислення, проведені в межах гештальтпсихології (М. Вертгеймер, К. Дункер) окреслили інший підхід до діагностики креативності, заснований на застосуванні експериментальних методів. Суттєвими принципами такого підходу стали: індивідуалізовані завдання тестів, вивчення процесу творчого мислення, а не його результат, активна участь експериментатора. Роботи Дж. Гілфорда і П. Торренса поклали початок нового етапу в розвитку діагностики креативності, заснованого на використанні стандартизованих тестів для вивчення творчого потенціалу людини. Істотною відмінністю нового підходу до діагностики креативності було вивчення останньої як самостійного фактора, що не зводиться до загальної розумової обдарованості. Після робіт вищезазначених учених, за твердженням О. Бєлової (2004), розрізнення інтелекту як загальної здібності до застосування знань і креативності як загальної здібності до їхнього 
перетворення стало загальноприйнятим, а тестологічне вивчення креативності виділилося в самостійну галузь психодіагностики (Анастази и Урбина, 2007).

Отже, ми виокремили тести, спрямовані на виявлення сформованості креативного мислення молодших школярів за ціле-мотиваційним компонентом, зокрема такі:

- Тест мотивації школяра до навчання у школі О. Ануфрієва та С. Костроміної.

- Тест-питальник мотивації досягнення А. Мехрабіяна, створений для виміру мотивації досягнення (ТМД), а також для діагностики двох узагальнених стійких мотивів особистості: мотиву прагнення до успіху i мотиву уникнення невдачі, де оцінюють, який із цих двох мотивів у випробуваного домінує.

У констатувальному зрізі всього взяло участь 225 учнів базових закладів загальної середньої освіти (КЗ «ЛНВК ЗОШ І-ІІ ступенів № 7 - природничий ліцей», Луцька спеціалізована школа I-III ступенів № 5, 3ОШ I-III ступенів смт. Сенкевичівка, ЗОШ I-III ступенів № 20 (м. Павлоград Дніпропетровської області), ЗОШ I-III ступенів №1 ім. І. Я. Франка м. Горохів), із них 109 учнів 3-го класу та 116 - 4-го. Відповідно - контрольна група (КГ) 114 та експериментальна група (ЕГ) 111 молодших школярів.

Так, тест визначення мотивації школяра до навчання у школі О. Ануфрієва, С. Костроміної (Додаток Б) дає нам можливість визначити, чи сформована мотивація молодших школярів до навчання та чи емоційно забарвлений їхній інтерес до навчального процесу загалом, у тому числі й навчання іноземної мови. Дітям пропонується відповісти на запитання анкети, використовуючи відповіді «так», «ні», «не знаю».

За кожну відповідь, що стоїть в анкеті на першому місці, нараховується 3 бали, на другому місці - 1 бал, на останньому місці - 0 балів. Максимальна оцінка - 30 балів. Зі зростанням кількості балів підвищується рівень мотивації. Щодо рівневого вияву бали розподілялися так:

30-25 балів - сформоване ставлення до себе як до школяра, висока навчальна активність (високий рівень);

24-15 бали - ставлення до себе як до школяра практично сформовано; позитивне ставлення до школи, але школа більше приваблює позашкільними справами (середній рівень);

14-10 балів $\boldsymbol{i}$ менше - ставлення до себе як до школяра не сформовано або негативне (початковий рівень).

Результати сформованості мотивації школяра до навчання за цілемотиваційним компонентом подаємо у таблиці 1.

Таблиця 1

Сформованість мотивації школяра до навчання у школі

\begin{tabular}{|c|c|c|c|c|c|c|c|}
\hline \multirow{2}{*}{$\begin{array}{c}\text { Показник сформованості } \\
\text { ціле-мотиваційного } \\
\text { компонента креативного } \\
\text { мислення }\end{array}$} & \multirow{2}{*}{ Групи } & \multicolumn{6}{|c|}{ Рівні } \\
\cline { 3 - 8 } & & Початковий & \multicolumn{2}{|c|}{ Середній } & \multicolumn{2}{|c|}{ Високий } \\
\cline { 3 - 8 } & Абс. & $\%$ & Абс. & $\%$ & Абс. & $\%$ \\
\hline $\begin{array}{c}\text { Мотивація школяра до } \\
\text { навчання }\end{array}$ & $\mathrm{E}$ & 59 & 52 & 50 & 44 & 5 & 4 \\
\cline { 3 - 8 } & КГ & 63 & 57 & 42 & 38 & 6 & 5 \\
\hline
\end{tabular}

Як бачимо 3 таблиці 1, більшість учнів не виявили високого рівня сформованості мотивації до навчання, тобто низький рівень $є$ домінантним, що свідчить про несформованість або часткову сформованість ставлення учнів до 
себе як до школяра, або негативне ставлення до школи загалом та відсутність емоційно забарвленого інтересу до навчання. Усе це демонструє низьку вмотивованість учнів до навчання, що, вочевидь, унеможливлює і мотивацію до вивчення іноземної мови, і розвитку креативного мислення у цьому процесі.

Тест-питальник мотивації досягнення А. Мехрабіяна для виміру мотивації досягнення (ТМД) запропонував М. Магомет-Емінов. ТМД призначений для діагностики двох узагальнених стійких мотивів особистості: мотиву прагнення до успіху і мотиву уникнення невдачі. Тест $є$ питальником, що має дві форми - чоловічу і жіночу.

Тест складається з 32 (для хлопчиків) та 30 (для дівчаток) тверджень, що стосуються певних сторін характеру, а також думок і почуттів із приводу деяких життєвих ситуацій та ключів. Щоб оцінити ступінь згоди або незгоди за кожним твердженням, використовується така шкала:

+3 - цілком погоджуюсь;

+2 - погоджуюсь;

+1 - швидше погоджуюсь, ніж не погоджуюсь;

0 - нейтральний;

-1 - швидше погоджуюсь, ніж не погоджуюсь;

-2 - не погоджуюсь;

-3 - цілком не погоджуюсь.

Якщо сума балів за ключами виявляється в інтервалі від 165 до 210, то робиться висновок про те, що в мотивації досягнення успіхів у даного випробуваного домінує прагнення до успіху (високий рівень). Якщо ця сума балів знаходиться в межах від 76 до 164, то робиться висновок про домінування прагнення уникати невдачі (середній рівень). Сума балів у межах від 30 до 75 дозволяє зробити висновок про відсутність домінування обох прагнень щодо мотивації - досягнення успіхів або уникнення невдач (початковий рівень). Результати сформованості мотивації досягнення за цілемотиваційним критерієм подано у таблиці 2.

Таблиця 2

Сформованість у молодших школярів мотивації досягнення

\begin{tabular}{|c|c|c|c|c|c|c|c|}
\hline \multirow{3}{*}{$\begin{array}{c}\text { Показник } \\
\text { сформованості ціле- } \\
\text { мотиваційного } \\
\text { компонента } \\
\text { креативного мислення } \\
\text { молодших школярів }\end{array}$} & \multirow{3}{*}{ Групи } & \multicolumn{6}{|c|}{ Рівні } \\
\hline & & \multicolumn{2}{|c|}{ Початковий } & \multicolumn{2}{|c|}{ Середній } & \multicolumn{2}{|c|}{ Високий } \\
\hline & & Абс. & $\%$ & Абс. & $\%$ & Абс. & $\%$ \\
\hline \multirow[t]{2}{*}{ Мотивачія досягнення } & $\mathrm{E} \Gamma$ & 62 & 56 & 49 & 44 & 0 & 0 \\
\hline & $\overline{\mathrm{K} \Gamma}$ & 67 & 59 & 47 & 41 & 0 & 0 \\
\hline
\end{tabular}

Аналіз результатів теста-питальника мотивації досягнення А. Мехрабіана забезпечує можливість констатувати, що ніхто із учнів не показав високого рівня сформованості мотивації досягнення, а лише середній та початковий рівні, оскільки сумарно учні набрали бали від 161 до 45, що є підставою зробити висновок про відсутність у молодших школярів прагнення до успіху, а натомість домінування прагнення уникати невдачі у навчанні, що, на наш погляд, є свідченням не сформованості у молодших школярів інтересу до оригінального, нестандартного. 
Відповідно до діагностувально-критеріального апарату дослідження нами був розроблений тест «Креативне мислення», який дає можливість визначити рівень сформованості креативного мислення молодших школярів у процесі вивчення іноземних мов. Для проведення тестування ми використовували формат A5 (пів-A4), а перед його початком учням зачитувалася коротка інструкція: «Діти, це завдання допоможе дізнатися, наскільки вам подобається вивчати іноземну мову та наскільки ви здатні креативно мислити при цьому. Вам пропонується 13 речень, навпроти яких потрібно поставити знаки «Х» чи «لฟ у графах «так», «ні», «не знаю / не визначився». На виконання завдання у вас є 10-15 хв. Не намагайтеся дати зразкові відповіді. Відповідайте так, як уважаєте за необхідне».

Відповіді на запитання «Мені подобається створювати щось нове», «Я завжди прагну до досконалості, самореалізації», «Я витрачаю більше часу на виконання домашнього завдання з англійської мови, тому що мені подобається цей предмет», «Я люблю розв'язувати завдання самостійно, без допомоги та підказок друзів і старших», «Мені цікава англійська мова, адже я можу проявити себе на уроці», «Мені подобається, коли під час уроку англійської мови відбувається швидка зміна різних видів діяльності», «Мені подобається виконувати завдання дослідницького характеру» та «Мені часто вдається знайти нестандартні, оригінальні шляхи виконання вправ» характеризують сформованість ціле-мотиваційного критерію, зокрема через розкриття таких показників, як: мотивація школяра до успішної навчальної діяльності та вивчення іноземної мови; інтерес до оригінального, нестандартного; емоційно забарвлений інтерес до вивчення іноземної мови.

Сформованість креативного мислення молодших школярів за результатами тестування за означеним компонентом подаємо у таблиці 3.

Таблиця 3

Сформованість креативного мислення молодших школярів за тестом «Креативне мислення» (ціле-мотиваційний компонент)

\begin{tabular}{|c|c|c|c|c|c|c|c|}
\hline \multirow{3}{*}{$\begin{array}{c}\text { Сформованість } \\
\text { креативного мислення } \\
\text { (ціле-мотиваційний } \\
\text { компонент) молодших } \\
\text { школярів }\end{array}$} & \multirow{3}{*}{ Групи } & \multicolumn{6}{|c|}{ Рівні } \\
\hline & & \multicolumn{2}{|c|}{ Початковий } & \multicolumn{2}{|c|}{ Середній } & \multicolumn{2}{|c|}{ Високий } \\
\hline & & Абс. & $\%$ & Абс. & $\%$ & Абс. & $\%$ \\
\hline \multirow{2}{*}{$\begin{array}{c}\text { За тестом «Креативне } \\
\text { мислення» }\end{array}$} & ЕГ & 57 & 51 & 50 & 45 & 4 & 4 \\
\hline & $\overline{\mathrm{K} \Gamma}$ & 64 & 56 & 47 & 41 & 3 & 3 \\
\hline
\end{tabular}

Дані таблиці 2.5 свідчать, що лише 4 \% та 3 \% молодших школярів мають високий рівень сформованості креативного мислення за ціле-мотиваційним компонентом, а домінантним є середній та початковий рівні. Отримані дані засвідчують недостатню вмотивованість учнів початкової школи до розвитку креативного мислення під час вивчення іноземної мови.

Узагальнення результатів діагностування щодо сформованості креативного мислення молодших школярів за ціле-мотиваційним компонентом подаємо в таблиці 4. 
Таблиця 4

Узагальнення результатів сформованості креативного мислення молодших школярів за ціле-мотиваційним компонентом

\begin{tabular}{|c|c|c|c|c|c|c|c|}
\hline \multirow{2}{*}{$\begin{array}{c}\text { Компонент } \\
\text { сформованості }\end{array}$} & \multicolumn{6}{|c|}{ Рівні } \\
\cline { 3 - 9 } $\begin{array}{c}\text { креативного мислення } \\
\text { молодших школярів }\end{array}$ & Групи & \multicolumn{2}{|c|}{ Початковий } & \multicolumn{2}{|c|}{ Середній } & \multicolumn{2}{|c|}{ Високий } \\
\cline { 3 - 9 } & & Абс. & $\%$ & Абс. & $\%$ & Абс. & $\%$ \\
\hline Ціле-мотиваційний & $\mathrm{E} Г$ & 60 & 54 & 49 & 44 & 2 & 2 \\
\cline { 3 - 9 } & КГ & 66 & 58 & 46 & 40 & 2 & 2 \\
\hline
\end{tabular}

Висновки і перспективи подальших розвідок. Отже, за результатами, поданими в таблиці 4, цілком правомірно зробити висновок про домінування початкового рівня сформованості креативного мислення учнів молодшого шкільного віку за ціле-мотиваційним компонентом, що засвідчує низьку вмотивованість учнів та унеможливлює бажання вивчати іноземну мову як ключовий предмет у контексті дослідження.

Перспективою подальших розвідок вбачаємо у виявленні реального рівня сформованості креативного мислення учнів молодшого шкільного віку за когнітивним компонентом.

\section{СПИСОК ВИКОРИСТАНИХ ДЖЕРЕЛ:}

Міністерство освіти і науки України, (2017). Громадське обговорення. URL: http://mon.gov.ua/citizens/zv\%E2\%80\%99yazki-z-gromadskistyu/konsultaczi-yi-zgromadskistyu/gromadske-obgovorennya-2017.html.

Мартиненко, С. (2010). Основи діагностичної діяльності вчителя початкової школи. Київ: Сім кольорів. 262 с.

Беспалько, В. (1989). Слагаемые педагогической технологии. Москва: Педагогика. 192 с.

Зотов, А. (1973). Структура научного мышления. Москва: Педагогика. 182 с.

Гуревич, К. и Борисова, Е. (1995). Психологическая диагностика детей и подростков. Москва: Междунар. пед. акад. 360 с.

Белова, Е. (2004). Одаренность малыша: раскрыть, понять, поддержать. Москва: Флинта. 140 с.

Анастази, А. и Урбина, С. (2007). Психологическое тестирование. СанктПетербург: Питер. 688 с.

\section{REFERENCES:}

Ministerstvo osvity i nauky Ukrainy, (2017). Hromadske obhovorennia. URL. [Public Debate]. URL:http://mon.gov.ua/citizens/zv\%E2\%80\%99yazki-zgromadskistyu/konsultaczi-yi-z-gromadskistyu/gromadske-obgovorennya-2017.html. [in Ukrainian]

Martynenko, S. (2010). Osnovy diahnostychnoi diialnosti vchytelia pochatkovoi shkoly. [Fundamentals of Diagnostic Activity of a Primary School Teacher: a teaching manual]. Kyiv: Sim koloriv. 262 s. [in Ukrainian]

Bespalko, V. (1989). Slagaemye pedagogicheskoj tehnologii [The Components of Educational Technology]. Moskva: Pedagogika. 192 s.[in Russian]

Zotov, A. (1973). Struktura nauchnogo myshlenija [Structure of Scientific Thinking]. Moskva: Pedagogika. 182 s. [in Russian]

Gurevich, K., Borisova, E. (1995) Psihologicheskaja diagnostika detej i podrostkov [Psychological Diagnosis of Children and Adolescents]. Moskva: Mezhdunar. ped. akad. 360 s. [in Russian] 
Belova, E. (2004). Odarennost' malysha: raskryt, ponjat, podderzhat [The Talent of the Child: to Reveal, Understand, Support]. Moskva: Flinta. 140 s. [in Russian]

Anastazi, A. \& Urbina, S. (2007) Psihologicheskoe testirovanie [Psychological Testing]. Sankt-Peterburg: Piter. 688 s. [in Russian]

\title{
THE REAL STATE OF FORMATION OF JUNIOR SCHOOLCHILDREN CREATIVE THINKING IN THE PROCESS OF FOREIGN LANGUAGE TEACHING: AIM-MOTIVATIONAL COMPONENT
}

\author{
Yulia Skrobaka \\ PhD in Pedagogy, \\ Lecturer of the English Language \\ Lutsk Pedagogical College, \\ Lutsk, Ukraine \\ ORCID: 0000-0001-5942-2783 \\ e-mail: chapiuk@ukr.net
}

\begin{abstract}
The article describes the real state of formation of creative thinking of junior schoolchildren in the process of learning foreign languages as the aim-motivated component as the key to the development of this phenomenon. Clarification on the interpretation of the concepts of "diagnosis" and "diagnostics" has been made. In a logical sequence methods are revealed, aimed at revealing the formation of creative thinking of junior pupils by the aim-motivational component. The importance of ascertaining stage of the experiment is generated, because the results of the formative stage is largely associated with the initial (source) condition of the phenomenon that is being studied and it gives the possibility of determining the actual state, in particular the formation of creative thinking of primary school pupils at foreign languages lessons. Tests are based on formation of primary school children creative thinking for the aim-motivational component, particularly, the test motivation of the children to study of V. Anufriev and $\mathrm{S}$. Kostromina and the questionnaire of achievement motivation of A. Mehrabian created to measure the motive desire for success and motive of avoiding of failure. The given tests give us the opportunity to determine whether the motivation of junior pupils for learning is formed and whether their interest to learning a foreign language is emotionally colored. It is provided in the article a test of "Creative thinking", which allows to determine the level of creative thinking formation of junior schoolchildren in the process of learning foreign languages according to aim-motivational component. The author emphasizes the insufficient level of formation of the motivational component in the development of creative thinking at foreign language lessons. The conclusion is made about the dominance of the initial level of creative thinking formation of junior schoolchildren for the aim-motivational component, which confirms the low motivation of children and makes the impossible desire to learn a foreign language as a key subject in the context of the study.
\end{abstract}

Key words: creative thinking, development, aim-motivated component, methodology.

Стаття надійшла до редакиії 02.03.2019 p. 